\title{
INTEGRASI BIOINVIGORASI BENIH PRATANAM DAN LEISA UNTUK MENINGKATKAN PERTUMBUHAN DAN HASIL PADI GOGO LOKAL (Oryza sativa L.)
}

\section{INTEGRATION OF PRE-PLANTING BIO-INVIGORATION SEEDS AND LEISA TO INCREASE GROWTH OF PRODUCTIVITY OF LOCAL UPLAND RICE (Oryza sativa L.)}

\author{
I Made Widanta ${ }^{1}$ Gusti Ayu Kade Sutariati ${ }^{2 *}$ La Ode Afa $^{2}$ \\ ${ }^{1}$ Mahasiswa Program Studi Agronomi Program Pascasarjana Universitas Halu Oleo \\ ${ }^{2}$ Dosen Program Studi Agronomi Program Pascasarjana Universitas Halu Oleo
}

Diterima: 5 Desember 2017/Disetujui: 28 Juli 2018

\begin{abstract}
This study amied to analyze the impact of integrating pre-planting bio-invigoration seed and LEISA on the growth and productivity of local upland rice. The study was carried out in Jati Bali, in the sub-district of West Ranomeeto, South Konawe regency, Southeast Sulawesi in 2016, using Split Plot design with Grouped Randomized Design, with factorial pattern including the first factor of pre-planting bio-invigoration seed $(B)$ consisting of two degrees namely a controlled one (without a treatment of bio-invigoration (BO) and red brick powder + Bacillus sp. CKD061 (B1). The second factor was LEISA (organic plus fertilizer + inorganic fertilizer) comprising of 6 degrees including a controlled one (G0), organic plus fertilizer 5 tons ha $a^{-1}(G 1)$, NPK fertilizer $250 \mathrm{~kg} \mathrm{ha}^{-1}(\mathrm{G} 2)$, organic plus fertilizer 5 tons ha ${ }^{-1}+$ NPK fertilizer $250 \mathrm{~kg}$ $\mathrm{ha}^{-1}(G 3)$, organic plus fertilizer 5 tons $\mathrm{ha}^{-1}+N P K$ fertilizer $125 \mathrm{~kg} \mathrm{ha}^{-1}(\mathrm{G} 4)$, organic plus fertilizer 5 tons ha ${ }^{-1}+N P K$ fertilizer $62,5 \mathrm{~kg} \mathrm{ha}^{-1}$ (G5). The study examined 12 combinations of treatment which were repeated 3 times to come up 36 experimental units. Data obtained from observation were analyzed using variance analysis and if the treatments showed real effects, the analysis was continued to DMRT test at a significance degree of $\alpha=0.05$.Results showed that the interaction between the treatments involving pre-planting bio-invigoration seeds (red brick powder + Bacillus sp. CKD061) and LEISA (organic plus fertilizer 5 tons $\mathrm{ha}^{-1}+N P K$ fertilizer $250 \mathrm{~kg} \mathrm{ha}^{-1}$ ) had real effects on the length of tassel, amount of tassel per grain, percentage of empty grains per tassel, and could increace the productivity up to 5,18 tons $\mathrm{ha}^{-1}$, which was the same as the treatment with red brick powder + Bacillus sp. CKD061 and organic plus fertilizer at a dosage of 5 ton $\mathrm{ha}^{-1}+$ NPK fertilizer $125 \mathrm{~kg} \mathrm{~h}^{-1}(\mathrm{BlG} 4)$, which was 5,13 ton ha $a^{-1}$ or each could increase the productivity by $70,96 \%$ and $69,31 \%$ as compared to the control groups. Individually, the pre-planting bio-invigoration seeds (red brick powder + Bacillus sp. CKD061) or LEISA (organic plus fertilizer + NPK fertilizer) had significantly real effect on the amount of productive tillers, lenght of tassels, amount of grains per tassel, percentage of empty grains per tassel, and productivity of local upland rice.
\end{abstract}

Keywords : rhizobacteria, bio-invigoration of seeds, LEISA, local upland rice

\section{ABSTRAK}

Penelitian ini bertujuan untuk mengkaji pengaruh integrasi bio-invigorasi benih pratanam dan LEISA terhadap pertumbuhan dan hasil tanaman padi gogo lokal. Penelitian dilaksanakan di Desa Jati Bali Kecamatan Ranomeeto Barat Kabupaten Konawe Selatan Provinsi Sulawesi Tenggara pada tahun 2016, menggunakan rancangan Split Plot dalam RAK (Rancangan Acak Kelompok) dengan pola faktorial yaitu faktor pertama bio-invigorasi benih pratanam (B) terdiri dari dua taraf yaitu kontrol (tanpa perlakuan bio-invigorasi) (B0) dan serbuk bata merah + Bacillus sp. CKD061 (B1). Faktor kedua LEISA (pupuk organik plus + pupuk anorganik) terdiri dari 6 taraf yaitu kontrol (G0), pupuk organik plus 5 ton ha ${ }^{-1}$ (G1), pupuk NPK $250 \mathrm{~kg} \mathrm{ha}^{-1}(\mathrm{G} 2)$, pupuk organik plus 5 ton ha ${ }^{-1}+$ pupuk NPK $250 \mathrm{~kg} \mathrm{ha}^{-1}$ (G3), pupuk organik plus 5 ton ha ${ }^{1}+$ pupuk NPK $125 \mathrm{~kg} \mathrm{ha}^{-1}$ (G4), pupuk organik plus 5 ton ha ${ }^{-1}$ + pupuk NPK 62,5 $\mathrm{kg} \mathrm{ha}^{-1}$ (G5). Perlakuan yang diuji 12 kombinasi perlakuan yang diulang 3 kali sehingga terdapat 36 unit percobaan. Data hasil pengamatan dianalisis dengan analisis ragam dan jika perlakuan berpengaruh nyata dilanjutkan dengan uji DMRT pada taraf kepercayaan $\alpha=0,05$. Hasil penelitian menunjukkan bahwa interaksi perlakuan bio-invigorasi benih pratanam (serbuk bata merah + Bacillus sp.

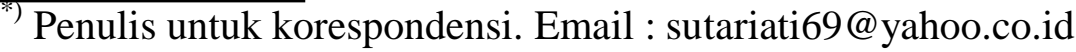


CKD061) dan LEISA (pupuk organik plus 5 ton ha ${ }^{-1}+$ pupuk NPK $250 \mathrm{~kg} \mathrm{ha}^{-1}$ ) berpengaruh nyata terhadap panjang malai, jumlah gabah per malai, persentase gabah hampa per malai, dan dapat meningkatkan produksi hingga 5,18 ton ha ${ }^{-1} \mathrm{yang}^{-1}$

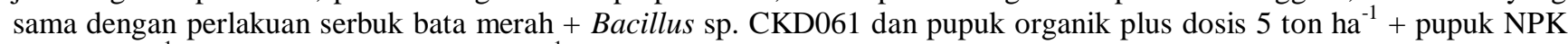
$125 \mathrm{~kg} \mathrm{ha}^{-1}$ (B1G4) yaitu 5,13 ton $\mathrm{ha}^{-1}$ atau masing-masing meningkatkan produksi sebesar 70,96\% dan 69,31\% dibandingkan dengan kontrol. Secara mandiri bio-invigorasi benih pratanam (serbuk bata merah + Bacillus sp. CKD061) atau LEISA (pupuk organik + pupuk NPK) berpengaruh sangat nyata terhadap jumlah anakan produktif, panjang malai, jumlah gabah per malai, persentase gabah hampa per malai, dan produksi padi gogo lokal.

Kata Kunci : Rizobakteri,Bio-Invigorasi Benih, LEISA, Padi Gogo Lokal

\section{PENDAHULUAN}

Sulawesi Tenggara memiliki luas wilayah 3.814.000 ha, dimana 3\% dimanfaatkan untuk lahan sawah, $69 \%$ lahan bukan sawah dan 28\% lahan untuk kepentingan lain (BPS, 2015). Potensi pengembangan pertanian pada lahan kering di Sulawesi Tenggara cukup luas. Untuk mendukung pemenuhan kebutuhan beras nasional, pengembangan budidaya padi gogo merupakan alternatif strategis dalam rangka pemenuhan kebutuhan beras nasional (Priatna, 2006). Padi gogo merupakan salah satu tanaman pangan yang berpotensi untuk dikembangkan di lahan kering (Widodo, 2004).

Luas panen padi gogo atau padi ladang di Sulawesi Tenggara seluas 5.377 ha, produksi 14.512 ton dan Produktivitas padi gogo di Sulawesi Tenggara masih rendah yaitu 2,70 ton ha ${ }^{-1}$, dibandingkan dengan rata-rata produktivitas nasional yaitu 3,34 ton ha $\mathrm{a}^{-1}$ (BPS, 2015). Produktivitas padi gogo yang rendah disebabkan oleh mutu benih yang rendah dan kesuburan tanah yang rendah.

Perbaikan mutu benih antara lain dapat dilakukan dengan cara bio-invigorasi benih yaitu menggunakan agensi hayati kelompok Rizobakteri seperti Bacillus sp. dan matriconditioning dengan menggunakan serbuk bata merah. Penggunaan rizobakteri secara mandiri telah terbukti efektif mampu meningkatkan berbagai pertumbuhan dan hasil tanaman cabai (Sutariati dan Wahab, 2012). Penggunaan rizobakteri dari golongan Bacillus sp., Pseudomonas sp. dan Serratia sp. telah banyak dilakukan dan terbukti memberikan efek yang lebih baik dalam meningkatkan pertumbuhan dan hasil tanaman (Junges et al., 2013). Penggunaan rizobakteri sebagai Plant Growth Promoting Rhizobacteria (PGPR), selain berperan sebagai pemacu pertumbuhan tanaman, juga berperan dalam meningkatkan ketahanan tanaman terhadap penyakit (Kloepper et al., 2004).

Rizobakteri dari golongan Bacillus menghasilkan hormon IAA (asam indol asetat) (Widayanti, 2007) dan mampu melarutkan posfat serta mensekresi siderofor dan berperan sebagai agen biokontrol dengan menginduksi sistem kekebalan tanaman serta antibiotik (Compant et al., 2005; Choudhary \& Johri, 2009).

Tingkat kesuburan tanah yang rendah dapat diatasi antara lain dengan pemberian pupuk organik dan pupuk anorganik dosis rendah, yang biasa dikenal dengan LEISA (Low External Input and Sustainable Agriculture). LEISA ini dilakukan dengan harapan dapat memperbaiki kesuburan tanah dan menjadikan sistem pertanian yang berkelanjutan. Oleh karena itu perlu dilakukan penelitian integrasi bio-invigorasi benih pratanam dan LEISA untuk meningkatkan pertumbuhan dan hasil tanaman padi gogo lokal.

\section{BAHAN DAN METODE}

Penelitian ini dilaksanakan di Desa Jati Bali Kecamatan Ranomeeto Barat Kabupaten Konawe Selatan Provinsi Sulawesi Tenggara, pada tahun 2016.

Bahan-bahan yang digunakan dalam penelitian ini adalah benih padi gogo lokal varietas Wangkomina, pupuk organik plus (Gaksi), pupuk NPK (15:15:15), isolat rizobakteri indigenus Bacillus sp. CKD061 (koleksi Prof. Dr. Ir. Gusti Ayu Kade Sutariati, M.Si), aquades, agar, plastik wrap, aluminium foil, kertas label, etanol $70 \%$, Trypthic Soy Broth (TSB), dan serbuk bata merah.

Alat-alat yang digunakan dalam pelaksanaan penelitian ini adalah gelas kimia, botol scott, oven, timbangan analitik, jarum ose, cawan petri, lampu bunsen, autoclave, laminar air flow cabinet, shaker, traktor, cangkul, tugal, kamera, mistar, meteran, balpoint, papan alas dan alat tulis lainnya.

Rancangan percobaan yang digunakan adalah Split Plot dalam Rancangan Acak Kelompok (RAK) yang terdiri dari bio-invigorasi benih pratanam (B) sebagai petak utama yang terdiri atas 2 (dua) taraf yaitu : B0 = Kontrol (tanpa aplikasi invigorasi), B1 = Serbuk Bata Merah + Bacillus sp. CKD061, dan LEISA (G) sebagai anak petak yang terdiri atas 6 (enam) taraf yaitu : G0 = Kontrol (tanpa aplikasi pupuk organik plus dan anorganik), G1 = Pupuk Organik Plus 5 ton $\mathrm{ha}^{-1}\left(8 \mathrm{~kg} \mathrm{petak}^{-1}\right), \mathrm{G} 2=$ Pupuk NPK $250 \mathrm{~kg} \mathrm{ha}^{-1}\left(400 \mathrm{~g} \mathrm{petak}^{-1}\right), \mathrm{G} 3=$ Pupuk Organik Plus 5 ton ha ${ }^{-1}\left(8 \mathrm{~kg}\right.$ petak $\left.^{-1}\right)+$ Pupuk NPK 
$250 \mathrm{~kg} \mathrm{ha}^{-1}\left(400 \mathrm{~g} \mathrm{petak}^{-1}\right), \mathrm{G} 4=$ Pupuk Organik Plus 5 ton ha ${ }^{-1}\left(8 \mathrm{~kg}\right.$ petak $\left.^{-1}\right)+$ Pupuk NPK $125 \mathrm{~kg} \mathrm{ha}^{-1}$ $\left(200 \mathrm{~g}\right.$ petak $\left.^{-1}\right), \mathrm{G} 5=$ Pupuk Organik Plus 5 ton ha ${ }^{-1}$ $\left(8 \mathrm{~kg}\right.$ petak $\left.^{-1}\right)+$ Pupuk NPK $62,5 \mathrm{~kg} \mathrm{ha}^{-1}(100 \mathrm{~g}$ petak $\left.^{-1}\right)$. Dengan demikian perlakuan yang diuji sebanyak 12 kombinasi perlakuan. Setiap perlakuan diulang $3 \mathrm{kali}$, sehingga terdapat 36 unit percobaan.

Bioinvigorasi benih pratanam dilakukan di Laboratorium dengan mencampurkan larutan yang telah diisi suspensi Bacillus sp. CKD061, serbuk bata merah dan benih padi gogo lokal. Setelah 12 jam benih dikering anginkan dan siap di tanam.

Penanaman dilakukan pada petak perlakuan yang telah disiapkan dengan jarak tanam $20 \times 30 \mathrm{~cm}$, kemudian dilakukan pemeliharaan yang meliputi penyiangan, penjarangan, penyulaman pemupukan dan panen.

Pemupukan dilakukan dengan pola LEISA sesuai dengan dosis perlakuan yang telah di tentukan. Pupuk organik plus diberikan pada saat pengolahan tanah, dan pemberian pupuk NPK (15:15:15) dilakukan dua kali yaitu setengah dosis pada saat tanaman berumur 1 minggu setelah tanam dan setengah dosis saat tanaman berumur 8 minggu setelah tanam pada setiap perlakuan.

Variabel pengamatan meliputi jumlah anakan produktif (anakan), panjang malai $(\mathrm{cm})$, jumlah

Tabel 1. Hasil analisis sidik ragam pertumbuhan dan hasil padi gogo lokal yang diberi perlakuan bio-invigorasi benih pratanam dan LEISA

\begin{tabular}{|c|c|c|c|c|}
\hline \multirow[b]{2}{*}{ No. } & \multirow[b]{2}{*}{ Variabel Pengamatan } & \multicolumn{3}{|c|}{ Uji F Perlakuan } \\
\hline & & $\begin{array}{l}\text { Bio- invigorasi } \\
\text { (B) }\end{array}$ & $\begin{array}{l}\text { LEISA } \\
\text { (G) }\end{array}$ & $\begin{array}{c}\text { Interaksi } \\
\left(B^{*} \mathbf{G}\right)\end{array}$ \\
\hline \multirow[t]{3}{*}{1.} & Pertumbuhan Vegetatif & & & \\
\hline & Jumlah Anakan Produktif (anakan) & $* *$ & $* *$ & tn \\
\hline & Laju Asimilasi Bersih/LAB $\left(\mathrm{g} \cdot \mathrm{cm}^{-1} \cdot\right.$ hari $\left.^{-1}\right)$ & $* *$ & $* *$ & tn \\
\hline \multirow[t]{5}{*}{2.} & Pertumbuhan Generatif & & & \\
\hline & Panjang Malai $(\mathrm{cm})$ & $* *$ & $* *$ & $*$ \\
\hline & Jumlah Gabah Per Malai (bulir) & $* *$ & $* *$ & $*$ \\
\hline & Persentase Gabah Hampa Per Malai (\%) & $* *$ & $* *$ & $* *$ \\
\hline & Produksi (ton/ha) & $* *$ & $* *$ & $* *$ \\
\hline
\end{tabular}

Keterangan : ** = berpengaruh sangat nyata, $*=$ berpengaruh nyata

Hasil penelitian menunjukkan bahwa pengaruh interaksi perlakuan bioinvigorasi benih pratanam menggunakan serbuk bata merah + Bacillus sp. CKD061 dan LEISA menggunakan pupuk organik plus + pupuk anorganik (B1G3) dapat memberikan peningkatan terhadap panjang malai, jumlah gabah per malai, dan produksi masing-masing 35,03\%, $63,23 \%, 70,96 \%$ dan dapat menurunkan persentase gabah hampa per malai sebesar $62,47 \%$ jika dibandingkan dengan kontrol. Namun dengan pengurangan $1 / 2$ dosis pupuk anorganik terjadi gabah per malai (butir), persentase gabah hampa per malai (\%), dan produksi (ton ha ${ }^{-1}$ ).

Data hasil pengamatan dianalisis dengan menggunakan analisis ragam atau ANOVA. Jika dalam hasil analisis menunjukkan $F_{\text {hitung }}>F_{\text {tabel }}$, maka dilanjutkan dengan Uji Jarak Berganda Duncan (UJBD) pada taraf nyata $\alpha=0,05$.

\section{HASIL DAN PEMBAHASAN}

Interaksi perlakuan bioinvigorasi benih pratanam dan LEISA berpengaruh nyata terhadap panjang malai, jumlah gabah per malai, persentase gabah hampa per malai, dan produksi. Pengaruh mandiri perlakuan bioinvigorasi benih pratanam berpengaruh sangat nyata terhadap jumlah anakan produktif, laju pertumbuhan absolut, panjang malai, jumlah gabah per malai, persentase gabah hampa per malai, dan produksi. Pengaruh mandiri perlakuan LEISA berpengaruh sangat nyata terhadap jumlah anakan produktif, panjang malai, jumlah gabah per malai, persentase gabah hampa per malai, dan produksi padi gogo lokal. Rekapitulasi hasil analisis sidik ragam pertumbuhan dan hasil padi gogo lokal yang diberi perlakuan bio-invigorasi benih pratanam dan LEISA disajikan pada Tabel 1. 
perlakuan bioinvigorasi benih pratanam dan LEISA disajikan pada Tabel 2.

Menurut Harjadi (1993) bahwa interaksi antara padi dengan faktor lingkungan dapat mempengaruhi pertumbuhan padi, faktor-faktor yang dapat mempengaruhi pertumbuhan dan produksi padi adalah tanah, iklim, biologis pupuk, pestisida dan varietas.

Peningkatan pertumbuhan dan hasil padi gogo lokal pada penelitian ini diduga disebabkan oleh peranan kombinasi perlakuan yang diberikan. Peranan Bacillus sp. CKD061 yang diberikan pada benih sebelum di tanam dan peranannya di dalam tanah yang mampu menghasilkan hormon pertumbuhan seperti IAA yang dapat merangsang pertumbuhan dan perkembangan akar halus dan akar rambut pada tanaman padi gogo lokal. Sutariati et al. (2012) melaporkan bahwa Bacillus sp. CKD061 mampu menghasilkan hormon IAA dan melarutkan fosfat yang dapat memacu perkecambahan benih sehingga menyebabkan percepatan pertumbuhan benih padi gogo lokal.

Agustiansyah et al. (2013) melaporkan hasil penelitiannya terhadap isolat bakteri dari akar padi bahwa isolat $B$. subtilis memiliki kemampuan menghambat pertumbuhan Xoo (Xantomonas oryzae pv. Oryzae) yaitu bakteri yang menyebabkan hawar daun pada tanaman padi dan dapat memproduksi IAA, enzim fosfatase, melarutkan fosfat, dan memiliki kandungan peroksidase. Di dalam peningkatan pertumbuhan tanaman padi gogo lokal pada penelitian ini, pupuk organik plus juga sangat berperan penting di dalam penyediaan unsur hara, perbaikan struktur tanah, perbaikan aerase tanah, meningkatkan KTK tanah, dapat menghambat ketersediaan ion logam seperti $\mathrm{Al}, \mathrm{Fe}$ dan $\mathrm{Mn}$ yang merupakan racun bagi tanaman, serta menjadi sumber energi dan makanan bagi mikroba tanah sehingga aktivitas mikroba di dalam tanah menjadi lebih baik (Kramany et al., 2007; Sitepu et al., 2010; Sheela dan Usharani, 2013). Namun demikian pemberian hanya dengan pupuk organik memberikan pengaruh yang lambat dalam meningkatkan pertumbuhan tanaman karena selain kandungan unsur haranya sedikit juga membutuhkan waktu yang lama untuk terdekomposisi dan tidak dapat di serap langsung oleh tanaman (Hakim, 1986), maka dari itu pemberian pupuk anorganik juga menjadi sangat penting di dalam meningkatkan pertumbuhan tanaman padi gogo lokal.
Gambar 1. Tanaman padi gogo lokal pada umur 8 mst

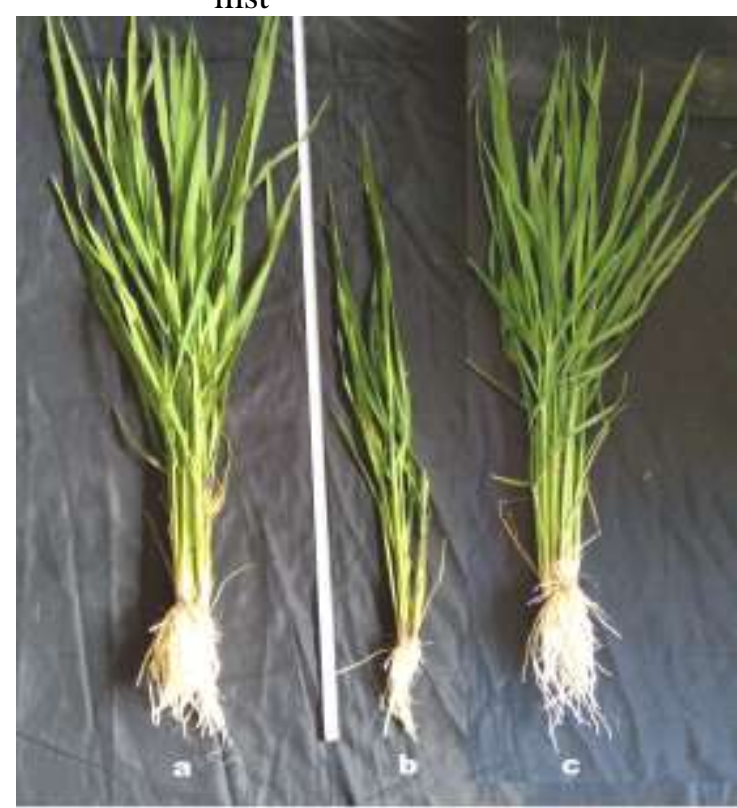

Keterangan : $\mathrm{a}=$ serbuk bata merah + Bacillus sp. CKD061 dan pupuk organik plus + pupuk anorganik (B1G3), b = kontrol (B0G0), c = serbuk bata merah + Bacillus sp. CKD061 dan pupuk organik plus $+1 / 2$ pupuk anorganik (B1G4).

Pupuk NPK diberikan ke dalam tanah untuk memenuhi kebutuhan unsur hara bagi pertumbuhan tanaman. Menurut Lingga (1986) bahwa pupuk N berperan dalam merangsang pertumbuhan anakan dan daun, unsur $\mathrm{P}$ berperan dalam pembentukan akar dan sistem perakaran tanaman, serta unsur $\mathrm{K}$ berperan dalam memperkuat vigor tanaman dan mempercepat pertumbuhan jaringan. Ketersediaan unsur hara yang cukup dan kesuburan tanah yang baik dapat meningkatkan pertumbuhan dan hasil produksi padi gogo lokal.

Laju Asimilasi Bersih (LAB) adalah laju peningkatan bobot kering tanaman pada saat tertentu tiap satuan luas (Hasanah et al., 2015). Kecukupan unsur hara dalam tanah yang dapat diserap oleh tanaman dalam proses pertumbuhan akan meningkatkan bobot kering tanaman. Hal tersebut dapat dilihat pada penampang tanaman (Gambar 1), yang menunjukkan bahwa dengan pemberian pupuk sesuai dosis anjuran (NPK $250 \mathrm{~kg} \mathrm{ha}^{-1}$ ) dan penggunaan setengah dosis anjuran (NPK $125 \mathrm{~kg}^{-}$ $\left.{ }^{1}\right)$ pada penelitian ini memberikan laju asimilasi bersih yang lebih baik dibandingkan dengan kontrol atau tanpa perlakuan. 
Tabel 2. Hasil uji DMRT rata-rata fase generatif tanaman padi gogo lokal yang diberi perlakuan bioinvigorasi benih pratanam dan LEISA

\begin{tabular}{|c|c|c|c|c|}
\hline \multirow[b]{2}{*}{ Perlakuan } & \multicolumn{4}{|c|}{ Fase Generatif } \\
\hline & $\begin{array}{l}\text { Panjang Malai } \\
(\mathrm{cm})\end{array}$ & $\begin{array}{c}\text { Jumlah Gabah Per } \\
\text { Malai (bulir) }\end{array}$ & $\begin{array}{c}\text { Persentase Gabah } \\
\text { Hampa Per Malai } \\
(\%)\end{array}$ & $\begin{array}{l}\text { Produksi (ton } \\
\text { ha-1) }\end{array}$ \\
\hline B0G0 & $35.60 \mathrm{~s}$ & $131.67 \mathrm{~s}$ & $34,45 \mathrm{p}$ & $3.03 \mathrm{r}$ \\
\hline B0G1 & $37.93 \mathrm{r}$ & $145.20 \mathrm{r}$ & $26,38 \mathrm{q}$ & $4.42 \mathrm{q}$ \\
\hline B0G2 & $41.87 \mathrm{q}$ & $175.73 \mathrm{pq}$ & $21,59 \mathrm{r}$ & $4.50 \mathrm{q}$ \\
\hline B0G3 & $44.13 \mathrm{p}$ & $182.40 \mathrm{p}$ & $18,61 \mathrm{t}$ & $4.68 \mathrm{p}$ \\
\hline B0G4 & $42.67 \mathrm{pq}$ & $176.80 \mathrm{p}$ & $20,21 \mathrm{~s}$ & $4.57 \mathrm{pq}$ \\
\hline B0G5 & $41.07 \mathrm{q}$ & $170.13 \mathrm{q}$ & $21,16 \mathrm{rs}$ & $4.50 \mathrm{q}$ \\
\hline B1G0 & $42.40 \mathrm{r}$ & $160.08 \mathrm{~s}$ & $24,20 \mathrm{p}$ & $3.76 \mathrm{r}$ \\
\hline B1G1 & $44.73 \mathrm{q}$ & $176.53 \mathrm{r}$ & $18,22 \mathrm{q}$ & $4.77 \mathrm{q}$ \\
\hline $\mathrm{B} 1 \mathrm{G} 2$ & $46.07 \mathrm{q}$ & $196.87 \mathrm{q}$ & $15,98 \mathrm{r}$ & $4.85 \mathrm{q}$ \\
\hline B1G3 & $48.07 \mathrm{p}$ & $214.93 p$ & $12,93 \mathrm{~s}$ & $5.18 \mathrm{p}$ \\
\hline B1G4 & $46.67 \mathrm{pq}$ & $211.13 \mathrm{p}$ & $13,64 \mathrm{~s}$ & $5.13 \mathrm{p}$ \\
\hline B1G5 & $44.73 \mathrm{q}$ & $192.60 \mathrm{q}$ & $16,93 \mathrm{r}$ & $4.82 \mathrm{q}$ \\
\hline
\end{tabular}

Keterangan : Angka-angka yang diikuti dengan huruf yang sama pada kolom yang sama menunjukkan tidak berbeda nyata pada DMRT $\alpha=0,05$

Peningkatan hasil produksi padi gogo lokal pada penelitian ini tentunya tidak terlepas dari peningkatan pertumbuhan baik pada pertumbuhan vegetatif seperti jumlah anakan produktif dan pertumbuhan generatif seperti panjang malai, jumlah gabah per malai, persentase gabah hampa per malai, dan produksi. Menurut Darwis (1979), panjang malai tanaman padi sangat mempengaruhi jumlah gabah per malai. Semakin panjang malai padi maka semakin banyak jumlah cabang malai dan jumlah gabah per malai, sehingga menghasilkan gabah yang lebih banyak per malai. Menurut Krisnawati (2007), penggunaan pupuk NPK dapat meningkatkan jumlah anakan, jumlah malai, berat gabah, bobot 1000 bulir dan hasil tanaman padi gogo. Aryanto et al. (2015) melaporkan bahwa perlakuan kompos pada tanaman padi sawah dan gogo yang diperkaya dengan mikroba (salah satunya Bacillus sp.) dan penambahan NPK dosis $50 \%$ memberikan hasil tertinggi. Penggunaan pupuk hayati dapat mengurangi penggunaan 50\% dosis pupuk NPK, dan juga dapat meningkatkan kualitas tanah masam. Kombinasi perlakuan bioinvigorasi benih pratanam dan LEISA selain memiliki pengaruh interaksi juga berpengaruh secara mandiri terhadap pertumbuhan dan hasil padi gogo lokal.
Gambar 2. Akar tanaman pada umur $8 \mathrm{mst}$

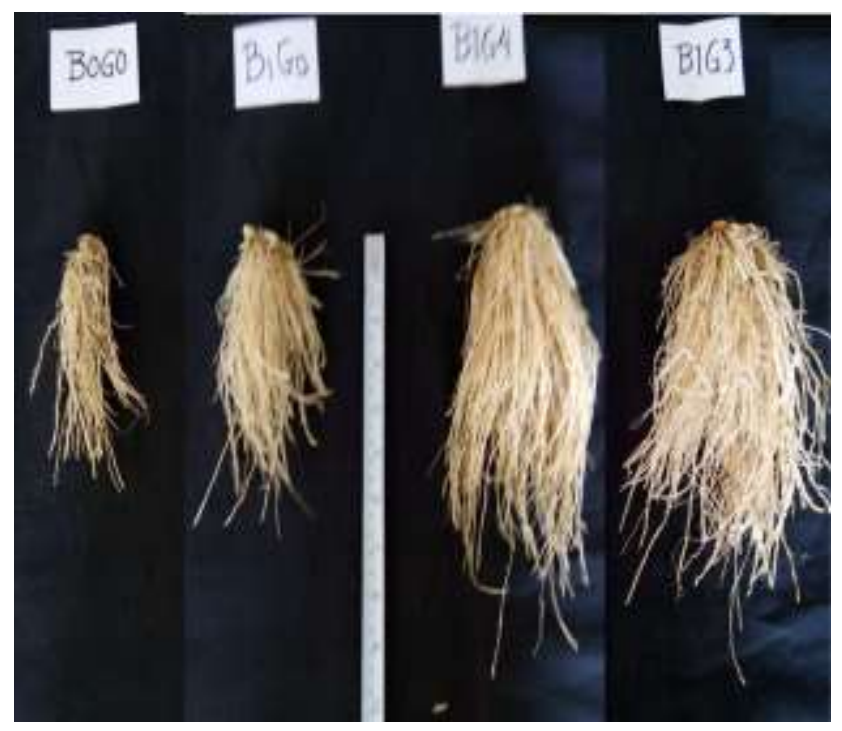

Keterangan : B0G0 $=$ kontrol, $\mathrm{B} 1 \mathrm{G} 0=$ serbuk bata merah + Bacillus sp. CKD061 dan tanpa LEISA, B1G3 = serbuk bata merah + Bacillus sp. CKD061 dan pupuk organik plus + pupuk anorganik, B1G4 $=$ serbuk bata merah + Bacillus sp. CKD061 dan pupuk organik plus $+1 / 2$ pupuk anorganik. 
Tabel 3. Pengaruh Mandiri Perlakuan Bioinvigorasi Benih Pratanam atau LEISA terhadap Pertumbuhan Tanaman Padi Gogo Lokal.

\begin{tabular}{|c|c|c|c|c|c|c|c|c|}
\hline \multirow{3}{*}{ Pertumbuhan Vegetatif } & \multicolumn{8}{|c|}{ Perlakuan } \\
\hline & \multicolumn{2}{|c|}{ Bioinvigorasi } & \multicolumn{6}{|c|}{ LEISA } \\
\hline & B0 & B1 & G0 & G1 & $\mathrm{G} 2$ & G3 & G4 & G5 \\
\hline Jumlah anakan produktif (anakan) & $8,060 \mathrm{~b}$ & $8,580 \mathrm{a}$ & $7,570 \mathrm{~d}$ & $8,000 \mathrm{c}$ & $8,370 \mathrm{~b}$ & $8,970 \mathrm{a}$ & $8,800 \mathrm{a}$ & $8,200 \mathrm{~b}$ \\
\hline $\begin{array}{l}\text { Laju Asimilasi Bersih/LAB (g.cm } \\
\left.{ }^{-} \text {.hari }{ }^{-1}\right)\end{array}$ & $0,015 \mathrm{a}$ & $0,015 \mathrm{a}$ & $0,013 \mathrm{~d}$ & $0,014 \mathrm{~cd}$ & $0,015 \mathrm{bc}$ & $0,017 \mathrm{a}$ & $0,016 \mathrm{ab}$ & $0,014 \mathrm{~cd}$ \\
\hline
\end{tabular}

Keterangan : Angka-angka yang diikuti dengan huruf yang sama pada baris (a,b,c,d) yang sama pada perlakuan yang sama menunjukkan tidak berbeda nyata pada DMRT $\alpha=0,05$

Pengaruh mandiri bioinvigorasi benih pratanam dengan menggunakan serbuk bata merah + Bacillus sp. CKD061 berpengaruh sangat nyata terhadap pertumbuhan dan hasil padi gogo lokal. Secara mandiri perlakuan bioinvigorasi benih pratanam dapat meningkatkan jumlah anakan produktif $6,45 \%$ jika dibandingkan dengan tanpa perlakuan bioinvigorasi benih pratanam (kontrol). Hal ini sesuai dengan hasil penelitian Faroq et al. (2006a) dan Fatoq et al. (2006b) bahwa perlakuan invigorasi dapat meningkatkan vigor benih, yang efeknya terlihat sampai fase vegetatif bahkan dapat meningkatkan hasil pada tanaman padi. Hasil penelitian serupa telah dilaporkan oleh Sucahyono et al. (2013) perlakuan matriconditioning dan matriconditioning + pupuk hayati berpengaruh positif terhadap viabilitas dan vigor benih kedelai hitam saat ditanam. Pengaruh dari media matriconditoning dalam hal ini serbuk bata merah yang digunakan mengakibatkan air yang tersedia untuk benih sangat sedikit karena menyerap air media tersebut, sehingga benih tidak menyerap air secara bebas dan proses metabolik terjadi secara sempurna karena ada perbaikan-perbaikan yang terjadi selama proses aktivasi yang menyebabkan ketika benih ditanam, benih dapat langsung tumbuh dan menampilkan performa yang lebih baik (Ashrafuzzaman et al., 2009).

Perlakuan mandiri LEISA berpengaruh sangat nyata terhadap pertumbuhan dan hasil padi gogo lokal. Pemberian pupuk organik plus ( 5 ton ha ${ }^{-1}$ atau $8 \mathrm{~kg}$ petak $\left.^{-1}\right)+$ pupuk anorganik $\left(250 \mathrm{~kg} \mathrm{ha}^{-1}\right.$ atau $\left.400 \mathrm{~g} \mathrm{petak}^{-1}\right)(\mathrm{G} 3)$ dapat meningkatkan jumlah anakan produktif $18,49 \%$ jika dibandingkan dengan kontrol, dan mampu meningkatkan hasil tanaman padi gogo lokal. Peningkatan ini diduga akibat pemberian pupuk organik plus dan pupuk anorganik (NPK) yang dapat meningkatkan ketersediaan unsur hara bagi tanaman padi gogo lokal sehingga nutrisinya terpenuhi dalam proses pertumbuhan dan perkembangannya. Pemberian pupuk organik plus ke dalam tanah dapat memperbaiki tingkat kesuburan tanah. Pupuk organik plus menyebabkan tanah lebih gembur sehingga akar tanaman lebih mudah untuk membentuk akar halus dan akar rambut, meningkatkan KTK tanah, memperbaiki aerase tanah, menjerap unsur-unsur beracun bagi tanaman seperti $\mathrm{Al}, \mathrm{Fe}$ dan $\mathrm{Mn}$, memperkaya bahan organik didalam tanah, serta dapat menjadi sumber energi dan makanan bagi organisme tanah sehingga aktivitas jasad renik didalam tanah menjadi lebih baik. Pupuk organik plus juga mengandung tiga jenis bakteri yang dapat mempercepat proses dekomposisi bahan organik yang diberikan dan juga dapat meningkatkan populasi mikroba di dalam tanah. Ketiga jenis bakteri ini mampu menghasilkan hormon tumbuh seperti IAA, giberelin dan sitokinin yang dapat merangsang pertumbuhan dan perkembangan tanaman (Kramany et al., 2007; Sitepu et al., 2010; Sheela dan Usharani, 2013). Hal ini sejalan dengan hasil penelitian Alavan et al. (2015) melaporkan bahwa pemupukan 50\% organik dan $50 \%$ anorganik merupakan pemupukan terbaik terhadap tinggi tanaman dan jumlah anakan per rumpun. Pemupukan 100\% organik merupakan perlakuan terbaik terhadap parameter umur berbunga dan umur panen.

Sutariati et al., (2014) menyatakan bahwa dengan pola kombinasi pupuk organik dan pupuk anorganik separuh dosis anjuran mampu meningkatkan pertumbuhan dan hasil bawang merah, hal ini lebih disebabkan oleh dosis yang diberikan telah mampu menyediakan kebutuhan unsur hara bagi tanaman dalam melangsungkan pertumbuhan terutama fase vegetatif. Menurut Hakim (1986) pemupukan adalah merupakan pemberian zat hara tanaman kedalam tanah yang bertujuan untuk memacu pertumbuhan dan perkembangan tanaman. Pupuk yang diberikan ke dalam tanah dapat berupa pupuk organik maupun pupuk anorganik. Pemupukan hanya dengan pupuk organik memberikan pengaruh yang lambat dalam meningkatkan pertumbuhan dan hasil tanaman karena membutuhkan waktu yang lama untuk terdekomposisi, dan unsur hara dalam pupuk organik tidak dapat langsung diserap oleh tanaman. 
Untuk memenuhi kebutuhan unsur hara tanaman padi gogo lokal perlu juga dilakukan pemberian pupuk anorganik (NPK). Pada penelitian ini, perlakuan pupuk NPK dosis $250 \mathrm{~kg} \mathrm{ha}^{-1}$ atau 400 $\mathrm{g} \operatorname{petak}^{-1}(\mathrm{G} 2)$ menunjukkan pertumbuhan dan hasil yang kurang baik dibandingkan dengan perlakuan yang dikombinasikan dengan pupuk organik plus. Hal ini diduga bahwa pupuk yang diberikan mengalami pencucian sehingga tidak dapat dimanfaatkan sepenuhnya dalam pertumbuhan dan perkembangan tanaman padi gogo lokal. Pemberian pupuk anorganik dalam dosis yang tinggi dan secara terus menerus juga dapat menurunkan pertubuhan dan hasil tanaman padi gogo lokal, hal ini disebabkan oleh residu bahan pupuk yang mengendap di dalam tanah sehingga menyebabkan kerusakan pada tanah yang berujung pada tanah tidak dapat digunakan secara berkelajutan.

\section{KESIMPULAN}

1. Interaksi perlakuan bio-invigorasi benih pratanam dan LEISA berpengaruh nyata terhadap panjang malai, jumlah gabah per malai dan berpengaruh sangat nyata terhadap persentase gabah hampa per malai, dan produksi padi gogo lokal.

2. Secara mandiri bio-invigorasi benih pratanam (serbuk bata merah + Bacillus sp. CKD061) berpengaruh sangat nyata terhadap jumlah anakan produktif, panjang malai, jumlah gabah per malai, persentase gabah hampa per malai, dan produksi padi gogo lokal, sedangkan LEISA (pupuk organik plus + pupuk anorganik) berpengaruh sangat nyata terhadap jumlah anakan produktif, panjang malai, jumlah gabah per malai, persentase gabah hampa per malai, dan produksi padi gogo lokal.

3. Integrasi bio-invigorasi benih pratanam dan LEISA menggunakan serbuk bata merah + Bacillus sp. CKD061 dan pupuk organik plus dosis 5 ton $\mathrm{ha}^{-1}+$ pupuk NPK $250 \mathrm{~kg} \mathrm{ha}^{-1}$ (B1G3) menghasilkan produksi tertinggi yaitu 5,18 ton ha $^{-1}$ yang sama dengan perlakuan serbuk bata merah + Bacillus sp. CKD061 dan pupuk organik plus dosis 5 ton $\mathrm{ha}^{-1}+$ pupuk NPK $125 \mathrm{~kg} \mathrm{ha}^{-1}$ (B1G4) yaitu 5,13 ton ha ${ }^{-1}$ atau masing-masing meningkatkan produksi sebesar $70,96 \%$ dan $69,31 \%$ dibandingkan dengan kontrol.

\section{DAFTAR PUSTAKA}

Agustiansyah, Ilyas S., Sudarsono, Machmud M., 2013. Karakterisasi Rizobakteri yang Berpotensi Mengendalikan Bakteri
Xantomonas Oryzae pv. Oryzae dan Meningkatkan Pertumbuhan Tanaman Padi. J. HPT Tropika. ISSN 1411-7525 Vol. 13, No. 1 : 42-51.

Alavan A., Hayati R., Hayati E., 2015. Pengaruh Pemupukan terhadap Pertumbuhan Beberapa Varietas Padi Gogo (Oryza sativa L.). Effect of Fertilization on Growth of Upland Rice Varieties (Oryza sativa L.). J. Floratek 10: 6168.

Aryanto A., Triadiati, Sugianta, 2015. Pertumbuhan dan Produksi Padi Sawah dan Gogo dengan Pemberian Pupuk Hayati Berbasis Bakteri Pemacu Tumbuh di Tanah Masam. Jurnal Ilmu Pertanian Indonesia Vol. 20 (3): 229-235.

Ashrafuzzaman M., Hossen F.A., Ismail M.R., Hoque M.A., Islam M.Z., Shahidullah S.M., Meon S., 2009. Efficiency of Plant GrowthPromoting Rhizobacteria (PGPR) for The Enhancement of Rice Growth. African Journal of Biotechnology Vol. 8 (7), pp. 1247-1252 ISSN 1684-5315.

Badan Pusat Statistik Sultra, 2015. Sultra Dalam Angka 2015, http://sultra.bps.go.id.

Darwis S.N., 1979. Agronomi Tanaman Padi I. Teori Pertumbuhan Dan Meningkatkat Hasil Padi. Lembaga Pusat Penelitian Pertanian Perwakilan Padang. 68 hal.

Farooq, M., Barsa, S.M.A., Wahid A., 2006a. Priming of field-sown rice enhances germination, seedling establishment, allometry and yield. Plant Growth Regul. 49:285-294.

Farooq, M., Basra S.M.A., Tabassum R., Afzal I., 2006b. Enhancing the performance of direct seeded fine rice by seed priming. Plant Prod. Sci. 9:446-456.

Harjadi, S.S. 1993. Pengantar Agronomi. Jakarta : Gramedia Pustaka Utama.

Hasanah Y., dan Rahmawati N., 2015. Analisis Pertumbuhan Kedelai di Lahan Kering dengan Aplikasi Bradyrhizobium japanicum Yang Diinduksi Genistein dan Pupuk Organik. Growth Analysis of Soybean Under Dry Land With Application of .... Induced By Genistein and Organic Fertilizer. Jurnal Pertanian Tropik Vol. 2, No. 2 ISSN : 2356-4725.

Junges, E., M. Toebe, R.F. dos Santos, G. Finger and M.F.B Muniz, 2013. Effect of Priming and Seed-coating When Associated With Bacillus subtilis in maize seed. Revista Ciencia Agronomica, Vol. 44 No. 3 Fortaleza. http://dx.doi.org/10.1590/ S180666902013000300014.

Kramany E.M.F., A. Bahar, F. Mohamad and M.O. Kabesf, 2007. Utilization of bio-fertilizer in 
field crops production 16-groundnut yield, its components and seed contents as affected by partial replacement of chemical fertilizers by bio-organic-fertilizers. Department of Field Crops Research National Research Center Dokki, Cairo, Egypt. Journal of Applied Science Research, 3(1): 25-29.

Krisnawati A., Adie M.M., 2007. Identifi kasi Galur Kedelai F5 Berbiji Besar dan Berumur Genjah. Plant Breeding Conference Proceeding 2007. Balai Penelitian Tanaman Kacang-Kacangan dan Umbi-umbian.

Lingga, P dan Marsono, 2000. Petunjuk Penggunaan Pupuk. Penebar Swadaya, Jakarta.

Priatna S., 2006. Evaluasi Pertumbuhan dan Produksi Padi Gogo Haploid Ganda Toleran Naungan dalam Sistem Tumpang Sari. Bul. Agron. (34)(2) $79-86$.

Sheela, T. And Usharani. 2013. Influence of plant growth promoting rhizobacteria (PGPR) on thegrowth of maize (Zea Mays L.). Golder Reseacrh Thoughts, 3(6): 1-4.

Sitepu I., Ignatia L., Franz A., Wong D., Faulina S., Tsui M., Kanti A., Boundy-Mills K., 2012. An improved high-throughput Nile red fluorescence assay for estimating intracellular lipids in a variety of yeast species. J. Microbiolog. 321-8.

Sucahyono D., Sari M., Surahman M., Ilyas S., 2013. Pengaruh Perlakuan Invigorasi Benih Kedelai Hitam terhadap Vigor Benih, Pertumbuhan Tanaman dan Hasil. Effect of Invigoration
Applied on Black Soybean (Glycine soja) Seed on Seed Vigor, Plant Growth, and Yield. J. Agron. Indonesia 41 (2) : $126-132$.

Sutariati GAK. dan A. Wahab, 2012. Karakter Fisiologi dan Kemangkusan Rizobakteri Indigenus sebagai Pemacu Pertumbuhan Tanaman Cabai. J. Hortikultura, Vol. 22 No. 1, p. $57-64$.

Sutariati G.A.K., Madiki A., Khaeruni A., 2014. Integrasi Teknik Invigorasi Benih dengan Rizobakteri untuk Pengendalian Penyakit dan Peningkatan Hasil Tomat. Integration of Seed Invigoration with Rhizobacteria to Control Disease and Improve Yield of Tomato. Jurnal Fitopatologi Indonesia Vol. 10 No. 6. ISSN : 0215-7950. 188-194.

Sutariati GAK., Leomo S., Rakian T.C., 2014. Keragaan Pertumbuhan dan Hasil Bawang Merah (Allium ascalonicum L.) pada Berbagai Ukuran Umbi dan Teknologi LEISA. Majalah Ilmiah Agriplus ISSN 0854 - 0128 Vol. 24.

Sutariati GAK., Safuan L., Khaeruni A. dan Handayani F., 2014. Uji Efektivitas Teknik Biopriming dan Sumber Benih Terhadap Viabilitas dan Vigor Bibit Kakao. Agriplus, Vol. 24 No. 2 p. 111 - 112.

Widodo, 2004. Pertumbuhan dan Hasil Padi Gogo cv. Cirata Terhadap 3 Jenis Media Tanam dan Ukuran Pupuk Urea. Jurusan Budidaya Pertanian, Fakultas Pertanian, UNIB. Jurnal Akta Agraria vol. 7 No. 1 Hal. 6-10. 